\title{
The Role of ICT in Social Capital Construction of Rural Female Entrepreneurship
}

\author{
Hongmei Huo ${ }^{1,2}$ \\ 1. College of Economics \& Management, Shenyang Agriculture University, Shenyang, 110866, \\ China
}

\author{
2. Liaoning Economics \& Politics College, Shenyang, 110004, China \\ E-mail:mm_huo@sina.com
}

Keywords: ICT;social capital; rural female; self-employment

\begin{abstract}
In this paper, ICT is proposed to create or strengthen social capital of rural female entrepreneurs. A model of the impaction of ICT on rural female social capital and self-employment was founded under the framework of social capital theory and entrepreneurship theory. A field survey conducted in Liaoling province was reported to valid the propositions by the author. The result indicated that the implement of ICT encouraged female rural entrepreneurs to create, maintain, and extend their bonding, bridging, and linking forms of social capital, and to impulse the entrepreneurs during self-employing, finally. Some suggestions about how to build social capital with ICT implementing and how to impel rural female to self-employ were put forward as the conclusion.
\end{abstract}

\section{Introduction}

Nowadays, more and more scholars pay attention to social capital theory, which has became a crucial theory on explaining the complicated entrepreneurial phenomenon. Social capital refers to opportunities arising from the knowledge of others, namely those within a social network. Social capital improves access to information leading to business opportunities, and at the same time, it improves both the entrepreneurial opportunity identification process and recognition capabilities, and the richer social capital an individual possesses, the more knowledge from the social network, and he or she will be able to incorporate and evaluate when entrepreneurial decision making. Social capital provides access to resources useful for entrepreneurship, such as labor resources and financial support. Social capital also provides timing advantages of self-employment and compensates shortfalls of human capital. Therefore, we can conclude that, social capital appears to be crucial for early start-up success and sustainable development.

ICT is the technology used for communicating, but also storing, retrieving and packaging information [1], usually, the technology that we referring to is computer, telephone and network. ICT takes great part in social and economic developing, so that the link between economic growth and ICT has been well established[2].

Recent years, there are abundant researches on social capital in many fields such as sociology, political science, economics and organization science. With the developing of information and communication technology, the relationship between ICT and social capital has been studied by IS researchers.

It is widely agreed that ICT (Information and Communication Technology) play a significant role in the development of developing countries in general and remote communities[3] [4] Recently, it was put forward by some researchers that ICT could be helpful in creating social capital in addition to human capital in remote countryside[5].

In this article the impaction of ICT on social capital of rural females and further influence on their self-employment are discussed, since many researches about the success of entrepreneurship have shown that social capital appears to be crucial for start-up success. The paper focuses on the role of ICT in rural female social capital constructing, and further impaction of ICT on rural female 
entrepreneurship. In another word, the author tries to answer the questions below: How does ICT create and extend social capital? And how does social capital foster rural female entrepreneurship?

The rest of the paper is organized as follows: Section 2 reviews the theory foundation of social capital, and related works on social capital, ICT and entrepreneurship; Section 3 constructs a theory framework of this paper, and goes on to develop a theoretical model for further research; Section 4 is the core part of the article, a research is taken up, and the data is analyzed and in this section. Section 5 is the summary. In this section, the gender difference of social capital and selfemployment is explained, and some advices are promoted.

\section{Theory Backgrounds}

Coleman (1988) defines social capital as a particular type of resource available to individual, and embedded in relations between people. Specifically, social capital is the ability to secure benefits by virtue of membership in social networks or other social structures. As a relational or networkmediated resource, social capital enables individuals or organizations to gain access to resources and opportunities, such as information and support as well as general economic means[6].

Social capital has three forms: bonding, bridging, and linking form[7]. Bonding and bridging form have resonance with the ideas of "strong ties" and "weak ties" respectively.

Research by Adam and Urquhart (2009) indicates that ICT facilitates the building of social capital through increasing flows of information. ICT can lead to create and maintain bridging, bonding and linking social capital. The more ICT used, the more bonding capital aroused[7]. Researcher found that wired residents had more contact with friends and relatives living outside their neighborhood.ICT provides an opportunity to create bridging and linking social capital, and at the same time, helps to maintain existing bonding social capital. Studies have shown that the Internet can help support and develop weak ties, by offering the social and technical potential for new ties to be realized.Other studies confirmed that ICT promote interactions among community participants that helped to generate and maintain the trust, acceptance, and alignment necessary for successful cooperation [6].

\section{The Theory Frame Work of the Research}

With respect to the gender differences in self-employment, many researches have found that there are significant gender differences in the business environment of male and female, financial and human capital endowments, and the preference of risk aversion. Furthermore, some researches demonstrated that female entrepreneurs' social capital is an important factor in self-employing, and determining the success of entrepreneurship finally .As to rural females, they lack of developing funds and education, acquire few training, and usually face obstacles from family, such as taking care of children and parents, and doing housework. The rate of rural female entrepreneurship is much lower than that of males and women in urban areas.

The difference of social gender existing in implementing and accessing to ICT is obviously observed, which can be seen not only between urban and rural areas, but also between men and women. Researches indicate that, in general, the level of the usage of ICT in rural areas is $64 \%$ behind that of city, and the gender DDI (Digital Divide Index) is 0.20 (means women lag 20\% behind men) in China. The existing of digital divide means that rural women lack access to information compare to their male counterparts. Furthermore, because of lacking of education and training, the capacity of rural women in grasping and implementing ICT is limited.

According to the analysis above, we believe that rural females have to face up with much restriction in self-employment. Since social capital plays a significant role in start-up, and an effective way to improve individual social capital is making good use of ICT, we hypothesize that the developing of ICT could improve rural women's social capital level by facilitating rural females accessing to resources useful for self-employment. In order to illustrate the problems we concerned, a model of the impaction of ICT on rural females' social capital building for self-employment will be developed as follows (see Fig. 1). 
According to Figure1, the development of ICT in rural areas plays a fundamental role in improving women to implement information technology. The development of ICT is composed of ICT infrastructure and ICT capacity building (or ICT knowledge training), which both leader by local government. With the implementation of ICT, rural females' social capital, such as bonding social capital, bridging and linking social capital will be creating, maintaining, and extending. And with the improvement of social capital, females could conquer different handicap in start-up.

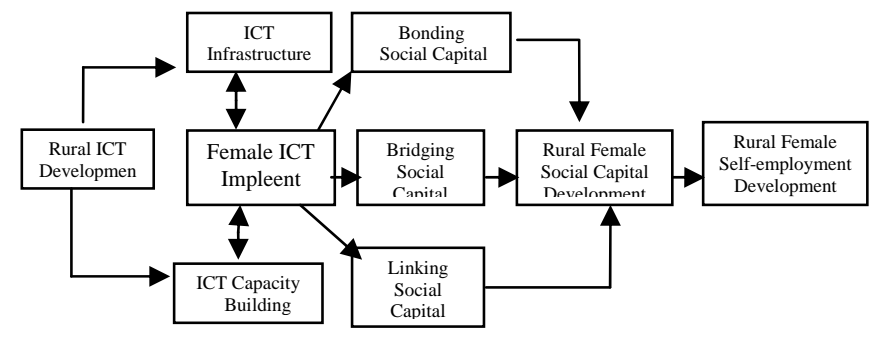

Figure 1. A model of the Impaction of ICT on Rural Female Social Capital and Self-employment

\section{Research}

The research has two targets: find out how ICT factor impact on social capital's constructing of rural female entrepreneurs, and go further to find out how ICT and social capital impact the performance of entrepreneurship.

Data of the research was collected by means of interviews, notes taking, observations, and questionnaire investigation based on social network analysis. The interviews were mainly semistructured, lasted from 15 to 55 minutes, and were tape-recorded. The research started up in July 2009, and finished in October 2009. The subjects of this research were rural entrepreneurs work in Dalian, Dandong, Shenyang, Anshan, and Fuxin city of Liaoning province. About 260 questionnaires were delivered, and 165 questionnaires came back from entrepreneurs, including 78 female entrepreneurs, and 87 male entrepreneurs. The social statistical software SPSS (10.0) is used to process datum collected by researchers.

The purpose of using ICT by rural entrepreneurs is mainly to connect with family, friends, and clients. The survey indicates that the connecting behavior of rural entrepreneurs is more frequency. Most respondents communicate with others "everyday" or "once a week" (sum of these two rates is 74.3\%) (see Table 1). Most rural entrepreneurs connect clients through telephone (75.9\%), and 20.9\% through internet (see Table 2).

The heterogeneity of female entrepreneurs' social network is higher than male entrepreneurs: $62.5 \%$ of women exchange information with men, and 37.5\% of women exchange information with men; while the rate of men is $91.1 \%$ and $9.9 \%$ respectively.

TABLE1.THE FREQUENCY OF INFORMATION EXCHANGE

\begin{tabular}{|l|c|c|c|}
\hline \multirow{2}{*}{ Communicatee } & \multicolumn{3}{|c|}{ Frequency of information exchanging } \\
\cline { 2 - 4 } & $\begin{array}{c}\text { Everyday } \\
\text { (\%) }\end{array}$ & $\begin{array}{c}\text { Once a week } \\
\text { (\%) }\end{array}$ & $\begin{array}{c}\text { Once a } \\
\text { month (\%) }\end{array}$ \\
\hline Family & 33.9 & 35.3 & 30.8 \\
\hline Relatives & 30.4 & 39.9 & 29.7 \\
\hline Friends & 39.5 & 41.4 & 19.1 \\
\hline Neighborhoods & 41.4 & 30.5 & 18.1 \\
\hline Business partners & 37.8 & 36.5 & 25.7 \\
\hline Others & 43.1 & 33.2 & 23.7 \\
\hline
\end{tabular}

TABLE2. THE WAY OF INFORMATION EXCHANGE

\begin{tabular}{|l|c|c|c|}
\hline \multirow{2}{*}{ Communicatee } & \multicolumn{3}{|c|}{ The way of information exchange } \\
\cline { 2 - 4 } & $\begin{array}{c}\text { Face to } \\
\text { face (\%) }\end{array}$ & $\begin{array}{c}\text { By telephone } \\
\text { (\%) }\end{array}$ & $\begin{array}{c}\text { By Internet } \\
\text { (\%) }\end{array}$ \\
\hline Family & 30.6 & 44.8 & 24.6 \\
\hline Relatives & 25.9 & 48.5 & 25.6 \\
\hline Friends & 35.3 & 43.2 & 21.5 \\
\hline Neighborhoods & 60.7 & 30.4 & 8.9 \\
\hline Business partners & 15.7 & 75.9 & 8.4 \\
\hline Others & 18.9 & 31.2 & 49.9 \\
\hline
\end{tabular}

Internet has become a significant way in communicating. QQ, e-mail, and BBS etc, have become common communication tools. This research also surveys the usage of these tools among rural entrepreneurs. It is believed that QQ is the most popular media, and utilized frequently by rural entrepreneurs. The chat and viewable function make QQ to be a familiar communication tools in rural entrepreneurs.

Lacking of knowledge of internet and bearing the burden of family, female rural entrepreneurs 
seldom access to computer, and master few kinds of internet communication tools. As we can see, $27.1 \%$ users of BBS is female entrepreneurs, and $72.9 \%$ is male entrepreneurs; $84.1 \%$ users of email is male entrepreneurs, and $16.9 \%$ is female entrepreneurs; while the difference in using QQ is not so obviously, which is $63.5 \%$ by men and $39.6 \%$ by women in rural entrepreneurs.

\section{Discussion}

It has been supported by the research above that the usage of ICT helps rural female entrepreneurs to create and extend social capital. The implement of ICT strengthen bonding, bridging and linking social capital of rural female entrepreneurs. The implement of ICT strengthens the connection between family and cooperation partners, even they locates in areas far away. Female entrepreneurs could access to and acquire resources available to self-employment.

The datum of the research revealed that the implement of ICT impacts rural entrepreneurs on the creation, maintenance and extension of the social capital. On the other hand, because of the poor infrastructure, high illiteracy rate, and lack of participation, females face barriers when make use of ICT to create, maintain and extend social capital for entrepreneurship.

Based on the research above, some suggestions are made as follows: Firstly, local government should increase budgetary funds and loans for ICT infrastructure. Local government should provide more technological support to rural areas, and build a platform for e-commerce, so as to decrease the cost of start-up of rural females. Secondly, the construction of e-government should be strengthened. In China, about $80 \%$ information is controlled by government, and most of them couldn't be shared by people. Thereby, governments should provide authoritative information and guidance for rural females to start their own business. Thirdly, rural women's knowledge on ICT and capacity of ICT implementing should be enhanced by local government, such as network or computer knowledge training of rural females. Finally, the women's federation should play a significant role in improve rural women's social capital and the ability of implementing ICT. A confraternity made up of rural females should be held, so that improves the participation and social capital of women in villages.

\section{Acknowledgment}

This paper is sponsored by Liaoning Planning Office of Philosophy an Social Science, (No.: L12BSH012).

\section{References}

[1]Bourdieu, P. The Forms of Capital, in J.G. Richardson (ed.) Handbook of Theory and Research for the Sociology of Education, New York: Greenwood,1986, pp. 241-258.

[2]Coleman, J.S. Social Capital in the Creation of Human Capital, The American Journal of Sociology, 1988.

[3]Granovetter, M. S. The Strength of Weak Ties. American Journal of Sociology, 1973, 78(6), 1360-1380.

[4]Adam, M. S., \& Urquhart, C. No man is an island: Social and human capital in IT capacity building in the Maldives. Information and Organization, 2009, 19(1), 1-21.

[5]Barr, A. (2000). Social capital and technical information flows in the Ghanaian manufacturing sector. Oxford Economic Papers, 2000, 52(3), 539-559.

[6]DCITA. The role of ICT in building communities and social capital. Australian Government Department of Communications Information Technology and the Arts. 2005.

[7]Lin, N. Social networks and status attainment. Annual Review of Sociology,1999, 25(1), 467. 